\title{
Orbital blowout trauma occurring at the workplace - clinical, biomechanical and legal aspects
}

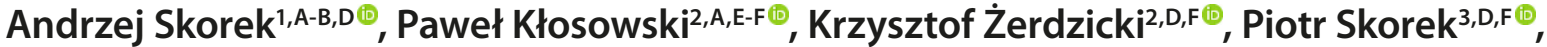 \\ Paweł Lemski ${ }^{1, B-C \odot}$, Marcin Zmuda-Trzebiatowski ${ }^{2, B-C, F} \odot$ \\ ${ }^{1}$ Department of Otolaryngology, Medical University, Gdańsk, Poland \\ ${ }^{2}$ Department of Structural Mechanics, Faculty of Civil and Environmental Engineering, University of Technology, Gdańsk, \\ Poland \\ ${ }^{3}$ Institute of Law and Administration, Pomeranian University, Słupsk, Poland \\ A - Research concept and design, B - Collection and/or assembly of data, C - Data analysis and interpretation, \\ $D$ - Writing the article, E - Critical revision of the article, F - Final approval of article
}

Skorek A, Kłosowski P, Żerdzicki K, Skorek P, Lemski P, Zmuda-Trzebiatowski M. Orbital blowout trauma occurring at the workplace - clinical, biomechanical and legal aspects. J Pre-Clin Clin Res. 2020; 14(2): 39-43. doi: 10.26444/jpccr/123656

\begin{abstract}
Introduction and objective. Craniofacial injury at the workplace may lead to orbital blowout fractures. The aim of the study is the development of own numerical model of the eye orbit, assessment of the damage zones, and comparing them with clinical examinations. In addition, the current legal status of patients after injuries is presented.

Materials and method. In laboratory tests performed on bones collected from the upper and medial orbital wall (examination on fresh corpses), the Young's modulus was determined for these bones. Based on the CT image, a numerical model of the eye orbit was created. The damage zones within the eye socket were assessed after a blow (dynamic model) to the inferior and lateral walls, and only to the inferior wall. Comparative clinical material were 9 patients with orbital blowout fracture treated at the Clinic of Otolaryngology

Results. Experiment 1: the damage zone covered an area of $0.54 \mathrm{~cm}^{2}$, and was located medially and laterally from the infraorbital nerve canal. Experiment 2: the damage zone was smaller $-0.38 \mathrm{~cm}^{2}$, and located medially to the infraorbital nerve canal. The results obtained in the experiment were compared with the CT image of the eye sockets of patients after injuries. On this basis, presumptions were made concerning the mechanism of the trauma.

Conclusions. The finite element method is a good tool for assessing the pathomechanism of trauma, as well as for an attempt to determine the circumstances of the event. Based on analysis of the numerical and clinical images, the necessity for using protective measures which absorb the impact to the inferior wall and temporal areas should be emphasised, as well as the fact that using merely goggles is insufficient protection of the eye orbit.
\end{abstract}

\section{Key words}

labour law, orbital trauma, numerical model of eye orbit

\section{INTRODUCTION}

Injuries to the eye socket are a difficult diagnostic and therapeutic problem, and their number continues to increase despite the use of various methods of head protection. Accidents at work are among the main causes of these injuries, apart from traffic accidents, assault, and accidents during practising sports $[1,2]$. The state after consumption of alcohol is an especially unfavourable predictive factor, which determines the size of the trauma, and simultaneously exerts an effect on the distant outcomes of treatment [2]. The consequence of injury to this site may be visual impairment, and often fractures of the bone structures constituting the orbital frame. In 1950, Converse and Smith introduced the term 'blowout' (synonyms: orbital blowout fracture, isolated orbital blowout fracture, isolated orbital floor fracture) to describe a fracture in which the orbital margin remains intact, while all destructive changes (fracture often with dislocation of bone fragments) take place some distance away

Address for correspondence: Andrzej Skorek, Department of Otolaryngology, Medical University, Gdańsk, Poland

E-mail: askorek@gumed.edu.pl

Received: 27.04.2020; accepted: 08.06.2020; first published: 18.06.2020
[3]. These fractures concern people at any age; however, most frequently they occur in young persons aged between $30-39$. There are two commonly accepted theories describing the mechanism of fracture: hydraulic and buckling. According to the first theory, the fracture occurs as a result of a force transmitted directly to the eyeball, whereas according to the second theory, the transmission of the force from a blow to the orbital margin. The effect of these forces is fracture of the orbital wall/walls (inferior and/or medial) [4].

Nagasao et al. were the first to apply the numerical model of the eye orbit (previous studies were conducted on corpses or dry skulls) for the assessment of the biomechanics of fractures. The model consisted of 824 triangular finite elements, whereas the material properties of the cranial bone (Young's modulus, thickness of individual walls) were based on its scanning. The results obtained corresponded with earlier studies conducted on corpses $[5,6]$. Later investigations by other researchers conducted with the use of a numerical model allowed precise assessment of the scope of the damage according to the force model, its direction, strength, and point of application $[7,8,9,10,11]$. 


\section{OBJECTIVE}

The aim of the study is assessment of the functioning of own numerical model with determination of the damage zones under the effect of dynamic blows directed towards the inferior and lateral walls, according to the buckling model, and comparing it with clinical and radiologic images of patients treated in the Otolaryngology Clinic. Clinical examinations were preceded by laboratory tests aimed at determination of the size of the Young's modulus of the orbital bones - the value of their strength and elasticity. Additionally, current legal aspects are discussed in detail concerning patients after orbital traumas occurring at the workplace.

\section{MATERIALS AND METHOD}

Laboratory tests. In order to determine the value of the Young's modulus, fragments of bones were collected from the upper and medial orbital walls from fresh corpses during medico-legal autopsy. After preparation of specimens, examinations of the mechanical properties were carried out at the Department of Structural Mechanics using a Zwick Z020 testing machine with video extensometer (Figs. 1 and 2). The values of the Young's modulus obtained remained within the range $0.12 \mathrm{GPa}-3.6 \mathrm{GPa}$ (according to the patient). The mean value adopted for further studies was $1.2 \mathrm{GPa}$. Based on the data from literature, the value of $150 \mathrm{MPa}$ was adopted as a strain threshold, above which there occurs damage/fracture of bones) $[6,7,8]$. Consent for the study was obtained from the Bioethics Committee.

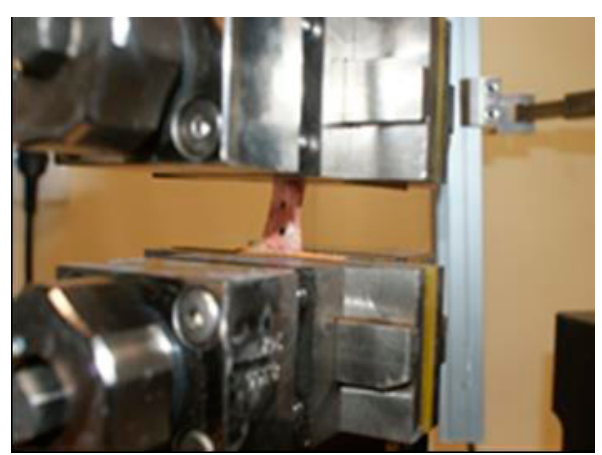

Figure 1. Mechanical bone examination using a Zwick Z020 strength testing machine with a videoextensometer

Numerical finite element model of the eye orbit. Using software AutoCAD 2012, a numerical model of the left orbit, together with the surrounding bones, was created, consisting of 969 triangular elements. In the model, the lower orbital fissure, optic nerve canal and the nasolacrimal duct outlet were taken into consideration. The model was created based on a computed tomography model of the facial skeleton performed in patients reporting to the Clinical Emergency Department for neurological reasons (including headache, vertigo syndrome, stroke). The authors excluded CT scans patients with past injuries and surgeries in the area of the facial skeleton, as well as diseases of the nose/sinuses and metabolic diseases. (These CT scans were most available, together with wide patients profiles - age, gender, free of additional diseases). Subsequently, the model was imported into the calculation software MSC.Marc/Mentat System 2012.

The computer model was subjected to overloads in time, in a dynamic calculation option. According to studies by other researchers, it was assumed that the maximum force occurred after approximately $1.3 \cdot 10^{-3} \mathrm{~s}$, while the complete cessation of the force was obtained after approximately $2.6 \cdot 10^{-3}$ s. $[6,7,10]$. In the first experiment, the model was assessed after using force applied to the nodal points located in the inferior wall ( 6 points located at the margin with the force of $2,400 \mathrm{~N}$ to each point), and the lateral wall (3 nodal points with the force of $4,800 \mathrm{~N}$ to each point). The total force was $28,800 \mathrm{~N}$. Both blows were shifted in time, i.e. the maximum force of the first blow (to the inferior wall) took place after the time of $t=1.3 \cdot 10^{-3} \mathrm{~s}$, whereas of the second blow (to the lateral wall) - after the time of $2.6 \cdot 10^{-3}$ s from the beginning of the test. Changes of strains within the orbital bone walls were observed. In the second experiment, the damage zone was evaluated in a model of a blow only to the inferior wall ( 6 points located at the margin with the force of $2,400 \mathrm{~N}$ to each point). The total force was $14,400 \mathrm{~N}$. The force vector was directed along the long axis of the eye orbit, determined by the axis of the optic nerve.

In both experiments, the strain zones were observed exceeding the threshold strain $(150 \mathrm{MPa})$, i.e. the strain above which there occurred damage of the bone structures. In both experiments, strain changes were assessed as a function of time, and the image where the damage was the greatest was selected for evaluation of the size and location. In Experiment 1, this happened after the time of $2.9 \cdot 10^{-3} \mathrm{~s}$, whereas in Experiment 2 - after the time of 2.6.10-3 s.

Clinical material. The radiological image (CT) and clinical data concerning 9 patients (Tab. 1) treated at the Otolaryngology Clinic due to orbital blowout trauma, were assessed. The traumas occurred at the workplace, and based on an interview with each patient it was confirmed that it was related with a double blow (the first to the lower orbital margin - with a blunt tool, metal splinter, construction element, whereas the second blow - an ordinary head blow from the ground, associated with falling), or an isolated blow to the inferior wall. The CT image was assessed in the horizontal and frontal planes to determine the location of fractures. The location of fractures was evaluated according to their location with respect to the outer rim of the orbit, inferior and lateral walls, and the infraorbital nerve canal. The radiologic image was compared with the pattern obtained on a numerical model (Figs. 3 and 4).

Table 1. Clinical data of treated patients

\begin{tabular}{lccccc}
\hline Patients & Gender & Age (y) & $\begin{array}{c}\text { Hit } \\
\text { mechanisms }\end{array}$ & $\begin{array}{c}\text { Fracture localisation } \\
\text { (orbital walls - CT scan) }\end{array}$ & $\begin{array}{c}\text { Surgery } \\
\text { treatment }\end{array}$ \\
\hline 1. & $\mathrm{M}$ & 27 & Isolated blow & lower & $\mathrm{Y}$ \\
\hline 2. & $\mathrm{M}$ & 35 & Isolated blow & lower & No \\
\hline 3. & $\mathrm{M}$ & 37 & Isolated blow & lower & $\mathrm{Y}$ \\
\hline 4. & $\mathrm{M}$ & 42 & Double blow & Lower, medial & $\mathrm{Y}$ \\
\hline 5. & $\mathrm{M}$ & 45 & Double blow & Lower, medial & $\mathrm{Y}$ \\
\hline 6. & $\mathrm{M}$ & 47 & Double blow & Lower, medial & $\mathrm{Y}$ \\
\hline 7. & $\mathrm{M}$ & 51 & Double blow & Lower, medial & $\mathrm{Y}$ \\
\hline 8. & $\mathrm{M}$ & 53 & Double blow & Lower, medial & $\mathrm{Y}$ \\
\hline 9. & $\mathrm{~F}$ & 34 & Isolated blow & lower & No \\
\hline
\end{tabular}




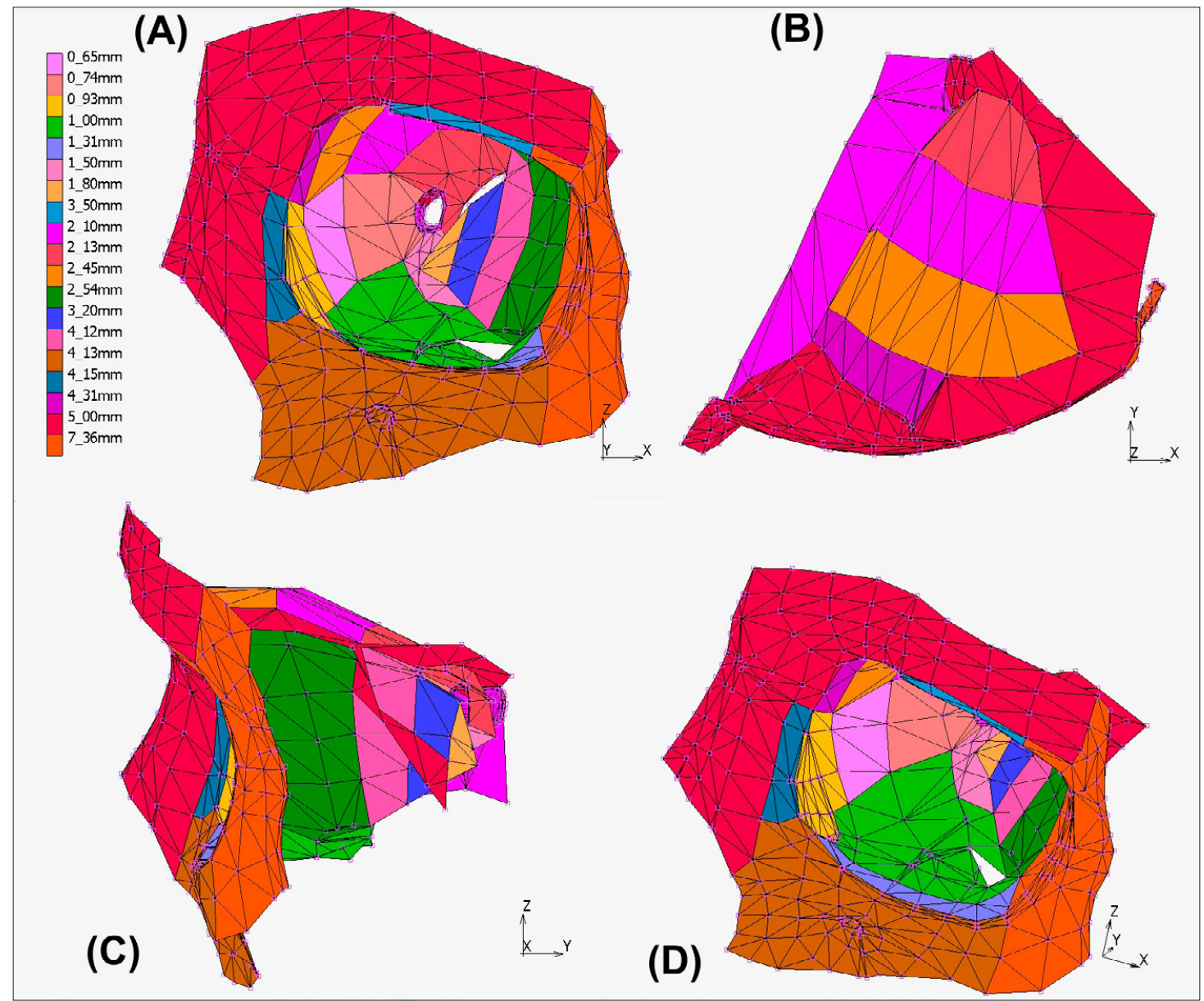

Figure 2. Numerical model of orbital bone structures

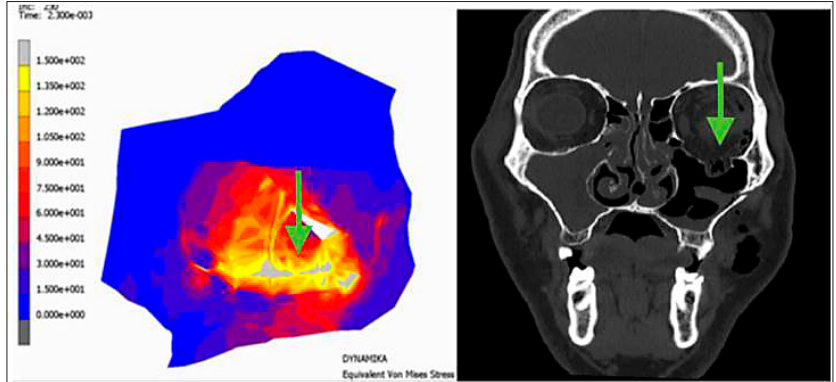

Figure 3. Patient after eye socket injury. CT image fracture in the lower wall with displacement of the orbital contents to the maxillary sinus (arrow). A comparable image obtained in the numerical model (arrow)

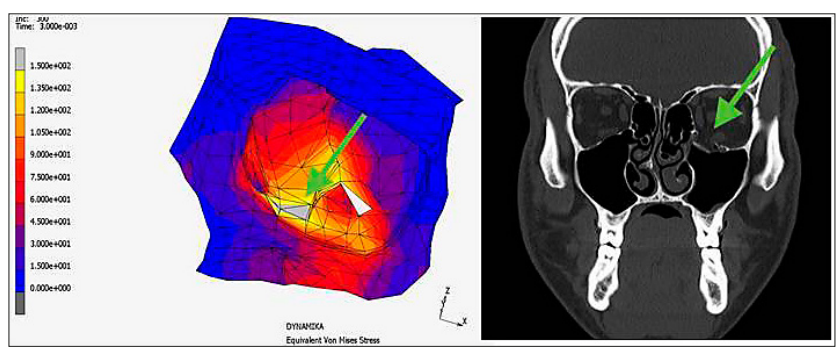

Figure 4. Patient after eye socket injury. CT scan - fracture within the lower wall medial part (arrow). A comparable image obtained in the numerical model (arrow)

\section{RESULTS}

Numerical model. Experiment 1: damage exceeding strain thresholds was observed medial to the infraorbital nerve canal and in the anterolateral part of the orbital floor; total surface area $-0.54 \mathrm{~cm}^{2}$. Experiment 2 : the damage was observed only medially to the infraorbital nerve canal; surface area $-0.8 \mathrm{~cm}^{2}$. In both experiments, high strain (over $130 \mathrm{MPa}$ ) was observed within practically the whole inferior wall, while a lower strain (but exceeding the value of $90 \mathrm{MPa}$ ) included the parabasal region within the medial and lateral walls.

Clinical examinations. In 5 patients in whom the mechanism of the trauma contained 2 components (a blow to the inferior wall and a blow to the lateral wall), fractures were observed covering the region medial and lateral to the optic canal. These fractures were often accompanied by a radiologic image of orbital oedema, accompanied by clinical symptoms of eyeball motility disorders and displacement (enophthalmos). In 4 patients who had undergone trauma consisting in a blow to the inferior wall, fracture was observed within the area of the inferior wall in the region medial to the infraorbital nerve canal. In all patients, the image of enophthalmos was observed with normal motility of the eyeball. 


\section{DISCUSSION}

Each orbital blowout trauma, apart from the medical aspect (symptomatology, radiologic image, selection of time and method of therapy), also had a biomechanical dimension (describing a complicated sequence of displacements and deformations concerning the whole bone walls and their particular elements), the dimension specifying and conditioning safety and hygiene of individual workplaces (considering the use of proper protective measures eliminating the effects of a blow to the site of the orbit), as well as a legal dimension (determination of damage zones according to the point/points and the strength of the force applied, allows the description of the circumstances of the event/accident). The relevant literature from the medical aspect is very comprehensive, whereas the remaining aspects of the trauma still remain the subject of research.

Biomechanics of orbital blowout trauma. Based on the numerical model, the damage (fractures) zone was determined in both mechanisms conditioning its occurrence. The selection of the force used in the experiment depended on the satisfaction of blowout injury conditions. When a greater force was applied, the damage occurred in the area of the outer rim of the orbit, while at its lower values, no areas were observed with strains exceeding the threshold value [1].

In the case of an isolated blow to the inferior wall, high strains involved the whole bony frame of the orbit (inferior wall and lower part of the medial wall); however, the fracture concerned only the area located medial to the infraorbital nerve canal. It should be emphasized that the average thickness of bones at this site did not differ from the remaining areas of this wall. In the case of a double blow, the area of fractures is larger than after the blow to the inferior wall only $\left(0.54 \mathrm{~cm}^{2}\right.$ vs. $\left.0.38 \mathrm{~cm}^{2}\right)$. In such cases, 'detachment' of the inferior wall from both the lateral and medial wall is usually observed, and 'greater' clinical symptoms occur.

It should be noted that the scope of fractures is not a simple sum of overlapping areas for both injuries - laterally from the infraorbital nerve canal in an isolated blow to the inferior wall strains rich the value of $135 \mathrm{MPa}$, whereas after a the double blow - the value of only 90MPa $[5,6]$. An explanation for this phenomenon is difficult, but is probably associated with different distribution and different way of transmission of the force in both types of blow. A separate problem is an attempt to recreate the blow pattern based on the damage zone. Into the study group were qualified only the patients in whom no fracture was observed within the outer bony frame of the orbit - meeting of the criterion for blowout trauma. While comparing the clinical image with the image of damage obtained during the experiments on a numerical model, it may be assumed that in the case of the presence of fractures concerning the lateral area of the orbital floor, a force must have been applied to the lateral orbital rim and directed perpendicularly to the long axis of the eye socket. This conclusion may be additionally applied in assessment of the circumstances and course of the event. However, a precise evaluation and interpretation of post-traumatic fractures still remains difficult and equivocal. While comparing the radiologic image with the image obtained in experiments on the model, it should be presumed that the scope of damage depends on the direction and points of application of forces. This may be of importance, both in the case of designing the protective measures, and in the case of conducting court/ medical investigations at a workplace $[5,6,7]$.

Legal aspects of accidents at work. Among blowout injuries, according to the causes of their occurrence, accidents at work constitute one-fourth. Limitation of the occurrence of these injuries is associated with the proper determination of the scope of duties and method of their application at a workplace, as well as the use of personal protection measures. At a workplace where the risk of injuries of this type occur, the use of regular protective glasses without the lower protective frame may be insufficient. The best solution is the facial screen and/or protective googles which, in the case of injury, rest on the facial bones and distribute and reduce the strength of a blow. Nevertheless, the googles must have extended side elements protecting the zygomatic orbital rim and the fronto-zygomatic junction.

However, a separate problem is the fact that among patients in the study, 7 out of 9 did not apply any protective measures, which is associated with the lack of predicting the possibility of such risk at their workplaces. The 2 remaining patients wore protective glasses but without a strengthened lower frame. It should be emphasized that the employer is obliged not only to provide the employee with personal protective equipment, including glasses, but also to enforce their use.

The majority of patients in the study sustained an injury while performing work activities related with construction, or involvement in traffic accidents. An adverse event was associated with an unintentional act, usually without the participation of third parties.

Polish legal standards in effect concerning the protection of the organ of vision arise from the validity of the standard EN $(166,169,170,171,172,175)$, and are consistent with EU directives $(89 / 655$ and 89/656) $[12,13]$. With relation to the filtering properties, these standards concern protection against radiation and protection against splash (molten metal and other welding particles). These standards also specify the mechanical strength of protective measures. However, although according to common opinion there is consent about the necessity to use protective measures at each workplace where exposure of the employee to splashes occurs, there are no unequivocal recommendations concerning their type, shape, and individual endurance. Among the patients in the current study, the basic recommendation should have been the use of protective equipment to protect the whole face, because the area of exposure due to the causative agent exceeded the size of the orbital region.

According to Article 3, Clause 1 of the Act currently in effect:

an accident at a work is considered a sudden event due to an external cause, resulting in an injury or death, which occurred in association with work, during or in relation with the performance by an employee of activities (regular or ordered by superiors) on the behalf of the employer (even without an order), or while the employee is at the employer's disposal on the way between the employer's seat and the place of performance of duty resulting from the employment relationship [14].

The preparation of an accident report is important for the employee $[15,16]$ because it not only confirms the occurrence of the event, but is also the starting point for initiation of the procedure for obtaining social insurance benefits. Lack of the above-mentioned document is the basis for refusing 
payment of benefits. If the event the accident is accepted as having occurred at work, the insured is entitled to benefits applied and paid by the insurer. These benefits include shortterm insurance benefits (sickness benefit, rehabilitation benefit, compensatory allowance), and long-term insurance benefits (disability pension, survivors' pension and training allowance), as well as compensation benefits for damage to health suffered by the insured person. The insurance is paid after the completion of treatment and rehabilitation; however, deficit in premiums may be a reason for not paying out insurance benefits [14]. According to Article 21, Clause 1 of the Accident Act: 'benefits from accident insurance are not payable if the sole cause of the accident at work was the violation (proved) by the insured person of regulations concerning the protection of health and life (A concept wider than $\mathrm{OSH}$ ), caused by this person intentionally or through gross negligence [14].' Also, pursuant to Article 21 Clause 2 of the above-mentioned Accident Act: 'benefits from the accident act will not be payable to the insured person if intoxicated or under the influence of drugs or psychotropic substances, and this state, to a great extent, contributed to causing the accident $[14,16,17]$.

\section{CONCLUSIONS}

1. Comparison of the damage zones on a numerical model and in patients after orbital blowout traumas allows determination of the direction of forces and their point of application.

2. Analysis of the trauma on a numerical model may determine its course and allow localization of the points which are especially important in designing new and/or existing protective measures.

\section{Acknowledgements}

The study was conducted within Project No. 016/23/B/ ST8/00115: 'Analysis of the mechanical properties of the eye orbital wall and the numerical nonlinear dynamic analysis of the orbital blowout trauma type verified by clinical observations' of the National Science Centre (NCN) in Kraków, Poland.

\section{REFERENCES}

1. Chi MJ, Ku M, Shin KH, Baek S. An analysis of 733 surgically treated blowout fractures. Ophthalmologica. 2009; 224: 167-175.

2. Kołpa M, Grochowska A, Gniadek A, Jurkiewicz B. Pourazowe obrażenia czaszkowo mózgowe u pacjentów w stanie nietrzeźwości, przyjmowanych doraźnie do szpitalnego oddziału ratunkowego. Med Og Nauk Zdr. 2016; 22(1): 40-45.

3. Converse JM, Smith B. Reconstruction of the floor of the orbit by bone grafts. Arch Ophthal. (Chicago). 1950; 44: 1-21.

4. Smith B, Regan WF. Blowout fracture of the orbit. Am J Ophtalmol. 1957; 44: 733-739.

5. Nagasao T, Kobayashi M, Tsuchiya Y, Kaneko T, Nakajima T. Finite element analysis of the stresses around fixtures in various reconstructed mandibular models part II (effect of horizontal load). J Craniomaxillofac Surg. 2003; 31: 168-175.

6. Nagasao T, Miyamoto J, Nagasao M, Ogata H, Kaneko T, Tamaki T, Nakajima T. The effect of striking angle on the buckling mechanizm in blowout fracture. Plast Reconstr Surg. 2006; 117: 2373-2380.

7. Nagasao T, Miyamoto J, Shimizu Y, Jiang H, Nakajima T. What happens between pure hydraulic and buckling mechanisms of blowout fractures. J Cranio-maxillofac Surg. 2010; 38: 306-313.

8. Nagasao T, Miyamoto J, Tamaki T, Kanazaki S, Ogawa K. Inferior meatal antrostomy impairs dynamic stability of the orbital walls. Auris Nasus Larynx. 2009; 36: 431-437.

9. Taddei F, Pancanti A, Viceconti M. An improved method for the automatic mapping of computer tomography numbers onto finite element models. Med Eng Phys. 2004; 26: 61-63.

10.Schaller A, Huempfner-Hierl H, Hemprich A, Hierl T. Biomechanical mechanisms of orbital wall fractures - a transient finite element analysis. J Craniomaxillofac Surg. 2013; 41: 710-717.

11. Foletti JM, Martinez V, Graillon N, Godio-Raboutet Y, Thollon L, Guyot L. Development and validation of an optimized finite element model of the human orbit. J Stomatol Oral Maxillofac Surg. 2019; 120: 16-20. doi: https://doi.org/10.1016/j.jorm

12. Zalecenia dotyczące doboru sprzętu ochrony oczu i twarzy chroniącego przed odpryskami ciał stałych. http://www.ciop.pl/1430.html (dostęp 2020. 03.30).

13. Podgórski D. Projekt PHARE. Dalsze przyjmowanie i wdrażanie prawa Unii Europejskiej w zakresie bezpieczeństwa i higieny pracy. Bezpieczeństwo Pracy. 2002/6. http://www.ciop.pl/8520 (dostęp 2020.03.30).

14. Ustawa z 30 października 2002r., o ubezpieczeniu społecznym z tytułu wypadku przy pracy i chorób zawodowych (tj. Dz. U z 2019 r. poz. $1205 \mathrm{z}$ późn. $\mathrm{zm}$.).

15. Rozporządzenie z dnia 1 lipca 2009 r., w sprawie ustalania okoliczności i przyczyn wypadku przy pracy (Dz. U. z 2009 r., Nr 105, poz. 870, ze zm. wydany na podstawie art. $237 \$ 1$ pkt1 k.p.).

16. Ustawa z dnia 17 grudnia 1998 r., o emeryturach i rentach z Funduszu Ubezpieczeń Społecznych (Dz. U z 2020 r. poz. 53 z późn.zm.).

17. Bińczycka-Majewska T. Charakterystyka i zakres świadczeń w systemie ubezpieczenia z tytułu wypadku przy pracy i chorób zawodowych. Praca i Zabezpieczenie Społeczne. 2003; 5, 20. 